\title{
Combined supplementation of chromium-yeast and selenium-yeast on finishing barrows
}

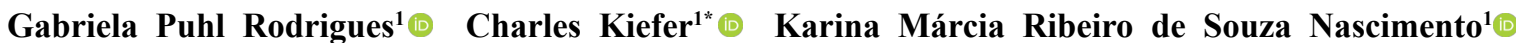

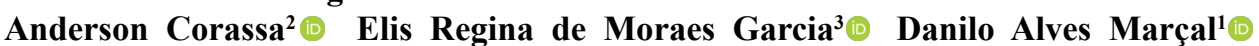 Camilla Mendonça Silva ${ }^{1}$ Gabriel Cipriano Rocha ${ }^{4}(\mathbb{0}$}

${ }^{1}$ Universidade Federal de Mato Grosso do Sul (UFMS), 79070-900, Campo Grande, MS, Brasil. E-mail: charles.kiefer@ufms.br. "Corresponding author. ${ }^{2}$ Universidade Federal de Mato Grosso (UFMT), Sinop, MT, Brasil.

${ }^{3}$ Universidade Estadual de Mato Grosso do Sul (UEMS), Aquidauana, MS, Brasil.

${ }^{4}$ Universidade Federal de Viçosa (UFV), Viçosa, MG, Brasil.

ABSTRACT: The present study was performed to evaluate the association of chromium-yeast and selenium-yeast as nutritional additives to enhance performance and quantitative characteristics in the carcass of finishing barrows. A total of 48 barrows, commercial hybrid, with initial weight of $68.3 \pm 3.5 \mathrm{~kg}$ and final weight of $99.6 \pm 3.6 \mathrm{~kg}$, were utilized for the study. The animals were distributed in a randomized complete block design, consisting of three levels of chromium-yeast and selenium-yeast (i.e., without supplementation of chromium-yeast and selenium-yeast, supplementation of $0.4 \mathrm{mg} \mathrm{kg-1}$ chromium-yeast and $0.3 \mathrm{mg} \mathrm{kg-1}$ selenium-yeast, and supplementation of $0.8 \mathrm{mg} \mathrm{kg-1}$ chromium-yeast and 0.6 $\mathrm{mg} \mathrm{kg}^{-1}$ selenium-yeast) with eight replicates and two animals per experimental unit. The supplementation of chromium and selenium-yeast did not significantly affect $(P>0.05)$ the average daily feed intake, digestible lysine, crude protein and metabolizable energy intake, average daily weight gain, feed conversion, weight and carcass length, back fat thickness, muscle depth, percentage and amount of lean meat, and carcass allowance. These findings suggest that supplementation of chromium and selenium-yeast does not affect the performance or quantitative characteristics in the carcass of finishing barrows.

Key words: feed additives, carcass characteristics, organic minerals, performance, swine.

Suplementação associada de cromo-levedura e selênio-levedura na dieta de suínos machos castrados em terminação

RESUMO: Realizou-se este estudo com o objetivo de avaliar a associação de cromo-levedura e selênio-levedura como aditivos nutricionais melhoradores de desempenho e das características quantitativas de carcaça de suínos machos castrados em terminação. Foram utilizados 48

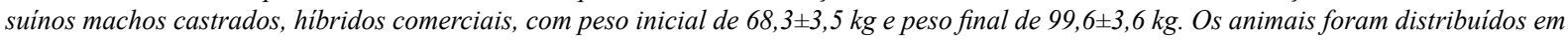
delineamento experimental de blocos casualizados, composto por três níveis de cromo-levedura e selênio-levedura (controle sem suplementação de cromo-levedura e selênio-levedura; suplementação de 0,4 $\mathrm{mg} \mathrm{kg}^{-1}$ de cromo-levedura e 0,3 $\mathrm{mg} \mathrm{kg-1}^{-1}$ de selênio-levedura; e 0,8 mg $\mathrm{kg}^{-1}$ de cromo-levedura e $0,6 \mathrm{mg} \mathrm{kg}^{-1}$ de selênio-levedura), com oito repetições e dois animais por unidade experimental. A suplementação de cromolevedura e selênio-levedura não influenciou $(P>0,05)$ o consumo de ração diário, os consumos de lisina digestível, de proteína bruta e de energia metabolizável, o ganho de peso diário, a conversão alimentar, o peso e comprimento de carcaça, espessura de toucinho, profundidade de músculo, percentagem e quantidade de carne magra e índice de bonificação. A suplementação associada de cromo e selênio-levedura não influencia o desempenho e as características quantitativas de carcaça de suínos machos castrados em terminação.

Palavras-chave: aditivos alimentares, características de carcaça, desempenho, minerais orgânicos, suínos.

\section{INTRODUCTION}

Minerals are nutrients that have roles in structural, physiological, immunological, reproductive, and growth functions in animals. Specifically, chromium acts as a constituent of the "Glucose Tolerance Factor," which amplifies insulin signaling and stimulates the uptake of glucose and amino acids by target cells (AMATA, 2013). Selenium acts as a constituent of the antioxidant enzyme glutathione peroxidase and is essential for the correct functioning of the immune system (ARTHUR et al., 2003). In addition, when in chelated form, these minerals have higher bioavailability 
than when in inorganic form, which increases their use as performance enhancers and carcass modifiers (SAKOMURA et al., 2014).

Chelated chromium has not shown consistent effects on performance and carcass characteristics of finishing pigs. Several studies have reported a positive effect of chelated chromium increasing weight gain, feed intake and lean meat deposition and decreasing fat deposition (LI et al., 2013; SALES \& JANCÍK, 2011), but others observed no improvement with supplementation (TIAN et al., 2014; TIAN et al., 2015; MARCOLLA et al., 2017).

Supplementation of chelated selenium for finishing pigs have shown an improvement of $9 \%$ on weight gain (JANG et al., 2010), 2\% on final body weight (MARTÍNEZ-GÓMEZ et al., 2012), besides improvements of $6 \%$ in muscle depth (CARAMORI JÚNIOR et al., 2017). However, divergent results have been obtained, some authors did not found differences in pig performance in the growingfinishing phases (STUPKA et al., 2012), indicating further studies need to be conducted to determine the effectiveness of chelated selenium in finishing pigs.

Studies that evaluated the combined use of chelated chromium and selenium supplementation in pigs are few and showed discrepant results (CARAMORI JÚNIOR et al., 2017). Therefore, the present study was performed to evaluate the association of chromium-yeast and selenium-yeast as nutritional additives to enhance performance and quantitative characteristics in the carcass of finishing barrows.

\section{MATERIALS AND METHODS}

A total of 48 barrows, commercial hybrid, with initial weight of $68.3 \pm 3.5 \mathrm{~kg}$ and final weight of $99.6 \pm 3.6 \mathrm{~kg}$, were utilized in the present study. The animals were housed in masonry pens $(1.25 \times 2.35$ $\mathrm{m})$, with concrete floors and shallow gutter, and were provided with semi-automatic feeders and pacifiertype automatic drinkers.

The environment variables assessed were mean environmental temperature, relative humidity and the black globe humidity index (BGHI). The mean environmental temperature during the experimental period was $27.5 \pm 2.0^{\circ} \mathrm{C}$, with a relative humidity of $73 \pm 10.9 \%$, black globe temperature of $27.8 \pm 2.0{ }^{\circ} \mathrm{C}$ and BGHI of $77.6 \pm 2.5$.

The animals were distributed in a randomized complete block design, with three treatment levels of chromium-yeast and seleniumyeast (i.e., without supplementation of chromium- yeast and selenium-yeast, supplementation of $0.4 \mathrm{mg}$ $\mathrm{kg}^{-1}$ chromium-yeast and $0.3 \mathrm{mg} \mathrm{kg}^{-1}$ selenium-yeast, and supplementation of $0.8 \mathrm{mg} \mathrm{kg}^{-1}$ chromium-yeast and $0.6 \mathrm{mg} \mathrm{kg}^{-1}$ selenium-yeast) with eight replicates and two animals per experimental unit. The pen was considered an experimental unit, with two animals per pen. The initial weights of the animals were used as the block formation criteria. The experimental diets were isonutritive and isocaloric and formulated to meet the nutritional requirements of high genetic-potential swine and for high performance (ROSTAGNO et al., 2011).

A vitamin-mineral supplement with 0.3 mg selenium $\mathrm{kg}^{-1}$ of diet obtained from sodium selenite was added to all diets. The selenium-yeast and chromium-yeast levels of the diets were obtained by adding the commercial product $\left(1,200 \mathrm{mg} \mathrm{kg}^{-1}\right.$ selenium-yeast and $1,600 \mathrm{mg} \mathrm{kg}^{-1}$ chromium yeast) replacing the kaolin (Table 1).

Feed and water were supplied ad libitum to the animals during the experimental period, which lasted 29 days. Feed waste was collected and weighed daily, and was added to the leftovers from the feeders at the end of the experiment to determine the average daily feed intake, metabolizable energy intake, apparent total tract digestibility (ATTD) of crude protein, and standardized ileal digestible lysine (SID-lys), obtained based on the estimation of the nutritional concentration of the diets and according to average daily feed intake of the animals.

The animals were weighed at the beginning and the end of the experimental period (no fasting) to determine the average daily weight gain and feed conversion rate. After that, pigs were fasted for $12 \mathrm{~h}$ and immediately transported by truck to the municipal commercial slaughterhouse, where they were kept in standby pens with free access to water for $8 \mathrm{~h}$. Specimens underwent desensitization and then bleeding, scalding, depilation, and evisceration. The carcasses were sawn lengthwise, up the spine, and divided into two halves to determine the carcass length, depth of the Longissimus dorsi muscle, and back fat thickness, according to the methodology described by BRIDI \& SILVA (2009).

The variables analyzed were the average daily feed intake, SID lysine, ATTD of crude protein and metabolizable energy, average daily weight gain, feed conversion rate, weight and hot carcass length, back fat thickness, muscle depth, percentage and amount of lean meat, and carcass allowance index. The hot carcass length measurements, back fat thickness at the height of the last rib, muscle depth, and percentage and amount of lean meat were obtained according to BRIDI \& SILVA (2009). The 
Table 1 - Nutritional and proximate composition of the basal diet for finishing barrows supplemented with chromium-yeast and selenium-yeast levels.

\begin{tabular}{|c|c|}
\hline \multicolumn{2}{|l|}{ Ingredient, $\mathrm{g} \mathrm{kg}^{-1}$} \\
\hline Corn & 779.88 \\
\hline Soybean meal, $46 \%$ & 192.99 \\
\hline Dicalcium phosphate & 8.06 \\
\hline Limestone & 6.49 \\
\hline Premix $^{1}$ & 4.00 \\
\hline Salt & 3.54 \\
\hline L-lysine $\mathrm{HCl} 78 \%$ & 2.56 \\
\hline DL-methionine $99 \%$ & 0.48 \\
\hline L-threonine $98 \%$ & 0.56 \\
\hline Chromium + Selenium-yeast $^{2}$ & 0.00 \\
\hline Inert (kaolin) $)^{3}$ & 1.44 \\
\hline \multicolumn{2}{|l|}{ Calculated nutritional composition ${ }^{4}$} \\
\hline Crude protein, $\mathrm{g} \mathrm{kg}^{-1}$ & 151.60 \\
\hline Metabolizable energy, $\mathrm{Kcal} \mathrm{kg}^{-1}$ & 3,230 \\
\hline Digestible lysine, $\mathrm{g} \mathrm{kg}^{-1}$ & 8.29 \\
\hline Digestible met+cist, $\mathrm{g} \mathrm{kg}^{-1}$ & 4.97 \\
\hline Digestible threonine, $\mathrm{g} \mathrm{kg}^{-1}$ & 5.55 \\
\hline Digestible thyptophan, $\mathrm{g} \mathrm{kg}^{-1}$ & 1.49 \\
\hline Calcium, $\mathrm{g} \mathrm{kg}^{-1}$ & 5.12 \\
\hline Digestible phosphorus, $\mathrm{g} \mathrm{kg}^{-1}$ & 2.48 \\
\hline Sodium, $\mathrm{g} \mathrm{kg}^{-1}$ & 1.60 \\
\hline
\end{tabular}

${ }^{1}$ Content per $\mathrm{kg}$ of feed: pantothenic acid $9.2 \mathrm{mg}$; niacin $18.0 \mathrm{mg}$; folic acid $0.5 \mathrm{mg}$; copper $15.0 \mathrm{mg}$; iron $10 \mathrm{mg}$; zinc $12.5 \mathrm{mg}$; iodine $1.0 \mathrm{mg}$; selenium $0.3 \mathrm{mg}$; manganese $5.0 \mathrm{mg}$; vitamin A 5.000UI; vitamin D3 1.000UI; vitamin E $25.0 \mathrm{UI}$; vitamin K3 $3.0 \mathrm{mg}$; vitamin B1 $1.5 \mathrm{mg}$; vitamin B2 $4.0 \mathrm{mg}$; vitamin B6 $1.5 \mathrm{mg}$ and vitamin B12 $1.8 \mathrm{mg}$.

${ }^{2}$ Content per kg of product: chromium $1,600 \mathrm{mg}$ and selenium $1,200 \mathrm{mg}$.

${ }^{3}$ Experimental diets were obtained by adding the commercial product at 0.25 and $0.50 \mathrm{~g} \mathrm{~kg}^{-1}$ into the basal diet, in replacement of inert (kaolin).

${ }^{4}$ Calculed based on the nutritional composition of raw materials (ROSTAGNO et al., 2011).

bonification index (BI) is a market strategy devised to encourage production of carcass with higher protein and lower deposited fat percentages and was established according to the following equation: $\mathrm{BI}$ $=23.6+(0.286 \times$ hot carcass weight $)+\%$ lean meat (BRIDI \& SILVA, 2007).

The data were submitted to an analysis of variance using the general linear model procedure and analyzed using the SAS statistical program (SAS Institute, Inc, Cary, NC, USA) at a 5\% significance level. The data were submitted to mean comparison analysis using Tukey's Test when significant differences were observed.

\section{RESULTS AND DISCUSSION}

The supplementation of chromium-yeast and selenium-yeast did not influence $(\mathrm{P}>0.05)$ the final weight, average daily feed intake, metabolizable energy, digestible protein and lysine, average daily weight gain, or feed conversion rate in the finishing barrows (Table 2). There are limited research studies that associate supplementation with chromium-yeast and chelated selenium in pig diets. STEFANKA et al. (2013) investigated the effects of the association of methionine selenium and chromium nicotine in the diets of finishing pigs and found no influence of this association on the final weight or on carcass characteristics.

The finding that chromium supplementation does not influence pig performance parameters has also been reported in studies utilizing chelated chromium not associated with selenium (MATTHEWS et al., 2005; TIAN et al., 2015). In addition, the supplementation of $0.4 \mathrm{mg} \mathrm{kg}^{-1}$ of chromium-yeast did not provide a positive effect on performance and carcass characteristics of pigs 
from 70 to $120 \mathrm{~kg}$ (MARCOLLA et al., 2017). Even for a long period of time (from 23 to $115 \mathrm{~kg}$ ) the supplementation of chromium in the diet was insufficient to improve the performance and carcass characteristics of the pigs (MATTHEWS et al., 2001).

On the other hand, LIEN et al. (2001) studied three levels of chromium picolinate $(0$, 0.2 , and $0.4 \mathrm{mg} \mathrm{kg}^{-1}$ ) for pigs from 46 to $110 \mathrm{~kg}$ and reported a $7 \%$ increase in weight gain when supplementation of 0.2 and $0.4 \mathrm{mg} \mathrm{kg}^{-1}$ was used over that in the control group. LI et al. (2013) and PERES et al. (2014) observed that the supplementation with chromium methionine for pigs during the whole finishing phase has potential to increase performance compared to non-supplemented treatments.

Concerning the selenium supplementation, the performance results obtained in the present study are in agreement with several previous studies that do not found significant effect of isolated supplementation selenium in pig diets (MATEO et al., 2007; STUPKA et al., 2012). In contrast, JANG et al. (2010) demonstrated that supplementation with $0.3 \mathrm{mg} \mathrm{kg}^{-1}$ of chelated selenium in swine diets during the growing and finishing phases (47 to $100 \mathrm{~kg}$ ) led to an increased weight gain of $9 \%$ for chelated selenium over that of the control group. In addition, MARTÍNEZ-GÓMEZ et al. (2012) demonstrated that pigs fed with $0.45 \mathrm{mg}$ $\mathrm{kg}^{-1}$ yeast enriched with chelated selenium (organic) exhibited higher final weights than animals fed with $0.45 \mathrm{mg} \mathrm{kg}^{-1}$ of sodium selenite (inorganic). These results reveal that the source of selenium may also influence the outcome of pig performance.

The combination of chromium-yeast and selenium-yeast did not significantly affect $(\mathrm{P}>0.05)$ the hot carcass weight, carcass length, back fat thickness, muscle depth, percentage and amount of lean meat, or the bonification index in the carcasses of finishing barrows. Similar results were obtained by STEFANKA et al. (2013) who demonstrated that the supplementation of $0.75 \mathrm{mg} \mathrm{kg}^{-1}$ of chromium nicotine associated with $0.3 \mathrm{mg} \mathrm{kg}^{-1}$ selenium methionine did not modify the carcass weight and thickness of pig fat during the finishing phase.

The isolated supplementation of 0.2 to 0.4 $\mathrm{mg} \mathrm{kg}^{-1}$ chromium picolinate or chromium propionate (MATTHEWS et al., 2001, 2005; ZHANG et al., 2011), in swine diets during the growing and finishing phases did not affect the quantitative characteristics of the carcass. Similarly, quantitative characteristics of the carcass were not influenced by the supplementation

Table 2 - Performance and carcass characteristics of finishing barrows supplemented with different concentrations of chromium-yeast and selenium-yeast.

\begin{tabular}{|c|c|c|c|c|c|}
\hline \multirow[t]{2}{*}{ Variable } & \multicolumn{3}{|c|}{--Chromium-yeast and selenium-yeast supplementation $\left(\mathrm{mg} \mathrm{kg}^{-1}\right)---$} & \multirow[t]{2}{*}{ CV (\%) } & \multirow[t]{2}{*}{ P-value } \\
\hline & $0 \mathrm{Cr} 0 \mathrm{Se}$ & $0.4 \mathrm{Cr} 0.3 \mathrm{Se}$ & $0.8 \mathrm{Cr} 0.6 \mathrm{Se}$ & & \\
\hline \multicolumn{6}{|c|}{ 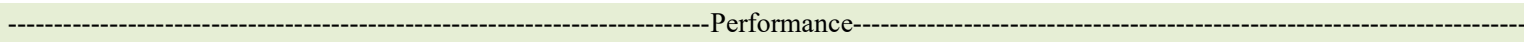 } \\
\hline Initial weight, $\mathrm{kg}$ & 68.17 & 68.43 & 68.36 & 1.03 & 0.962 \\
\hline Final BW, kg & 100.79 & 99.70 & 100.44 & 2.90 & 0.882 \\
\hline ADFI, kg & 2.96 & 2.91 & 2.96 & 4.09 & 0.730 \\
\hline MEI, Mcal day ${ }^{-1}$ & 9.32 & 9.35 & 9.51 & 4.09 & 0.732 \\
\hline DIP, g day $^{-1}$ & 437.55 & 439.12 & 446.74 & 4.09 & 0.732 \\
\hline LYSI, g day ${ }^{-1}$ & 23.92 & 24.01 & 24.42 & 4.09 & 0.732 \\
\hline $\mathrm{ADG}, \mathrm{kg}$ day $^{-1}$ & 1.12 & 1.08 & 1.11 & 7.21 & 0.783 \\
\hline $\mathrm{F}: \mathrm{G}$ & 2.63 & 2.70 & 2.68 & 4.75 & 0.692 \\
\hline \multicolumn{6}{|c|}{ 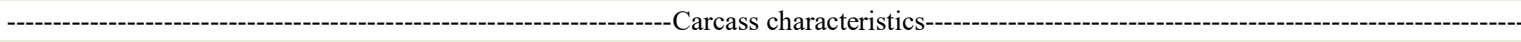 } \\
\hline $\mathrm{HCW}, \mathrm{kg}$ & 72.47 & 72.87 & 72.43 & 3.19 & 0.860 \\
\hline $\mathrm{CL}, \mathrm{cm}$ & 93.94 & 93.19 & 93.90 & 2.95 & 0.860 \\
\hline $\mathrm{BT}, \mathrm{mm}$ & 8.33 & 8.34 & 8.70 & 20.76 & 0.231 \\
\hline $\mathrm{MD}, \mathrm{mm}$ & 77.24 & 78.49 & 77.13 & 6.14 & 0.727 \\
\hline PLM, \% & 62.89 & 63.01 & 62.67 & 2.15 & 0.316 \\
\hline ALM, kg & 45.60 & 45.90 & 45.41 & 4.00 & 0.492 \\
\hline BI, \% & 107.22 & 107.45 & 106.99 & 1.44 & 0.315 \\
\hline
\end{tabular}

Final $\mathrm{BW}=$ final body weight; $\mathrm{ADFI}=$ average daily feed intake; MEI = Metabolizable energy intake; DIP = Protein intake; LYSI = Lysine intake; $\mathrm{ADG}=$ average daily gain; $\mathrm{F}: \mathrm{G}=$ feed conversion; $\mathrm{HCW}=$ Hot carcass weight; $\mathrm{CL}=\mathrm{Carcass}$ length; $\mathrm{BT}=\mathrm{Backfat}$ thickness; $\mathrm{MD}=$ Muscle depth; PLM = Percentage of lean meat; ALM = Amount of lean meat; BI = bonification index. 
of $0.2 \mathrm{mg} \mathrm{kg}^{-1}$ chromium methionine (chelated) and chromium sulfate (inorganic) in the diet of finishing pigs (PERES et al., 2014).

However, a positive response to chromium supplementation was observed by SALES \& JANCÍK (2011) from their meta-analysis study concluding that chromium supplementation in the diet of pigs during the growing and finishing stages decreased fat and increased the deposition of lean meat in the carcass. In contrast, WOLTER et al. (1999) showed that pigs in the growing and finishing stages (22 to $110 \mathrm{~kg}$ ), supplemented with yeast enriched with selenium, showed a decrease of approximately $15 \%$ in back fat thickness and increase of 7\% in the rib eye area.

An associated effect between chromiumyeast and selenium-yeast was expected for the performance characteristics and quantitative characteristics of the carcass owing to the action mechanisms of each nutrient, which might be enhanced by this association. The main function of chromium is to maintain glucose homeostasis by increasing sensitivity to insulin (insulin potentiation), consequently increasing the uptake of glucose and amino acids (AMATA, 2013). Selenium is essential for proper immunity functions of animals, it is a component of glutathione peroxidase an enzyme whose main role is to destroy free radicals and protect the organism from oxidative damage. Lymphocytes $\mathrm{T}$ and $\mathrm{B}$ form the major cells of the acquired system and mature with exposure to immune challenges. Selenium-deficient lymphocytes are less able to proliferate in response to mitogen, and in macrophages, the synthesis of leukotriene B4, which is essential for neutrophil chemotaxis, is also impaired by selenium deficiency. In addition, selenium protects macrophages and leukocytes against toxic compounds secreted by ingested bacteria and antibody titers and phagocytosis (ARTHUR et al., 2003). Organic selenium has been shown to be more effective than inorganic to improve immune system status (KUMAR et al., 2009) and therefore, is essential for the efficient operation of the immune system in animals and, if not available in the necessary quantities, might result in the immune response being impaired (ARTHUR et al., 2003).

The environment temperature observed $\left(27.5 \pm 2.0^{\circ} \mathrm{C}\right)$ during the experimental period can be considered above ideal for finishing pigs (NIENABER et al., 1987). However, it cannot be affirmed that the pigs of the present study were submitted to thermal challenge environment considering that the pigs feed intake and weight gain observed are in agreement with the Brazilian Poultry and Swine Tables (ROSTAGNO et al., 2011). Thus, there was not enough thermal challenges to express the possible beneficial effects owing the supplementation of chromium-yeast and selenium-yeast, which may explain the nonsignificant results obtained.

The contradictory results in the literature regarding chromium and selenium supplementation in pig diets may be related to the supplementation period and type of supplementation, the nutritional status of the pigs, the chromium and selenium sources, and the sanitary conditions to which the animals were exposed.

The nutritional recommendation of inorganic selenium for finishing pigs (70 to $100 \mathrm{~kg}$ ) is $0.21 \mathrm{mg} \mathrm{kg}^{-1}$ (ROSTAGNO et al., 2017), however, in the present study the premix used provided $0.3 \mathrm{mg}$ kg-1 of inorganic selenium. These facts could explain the lack of response to the initial supplementation of $0.6 \mathrm{mg} \mathrm{kg}^{-1}$ of organic selenium.

There is no chromium nutritional recommendation established in the literature for finishing pigs (ROSTAGNO et al., 2017). Thus, even with the absence of chromium in the premix used, the animals did not respond to $0.8 \mathrm{mg} \mathrm{kg}$ supplementation of organic chromium. For this reason, we recommend further studies aiming at elucidating the nutritional requirements of chromium for finishing pigs in order to better understand the results observed for organic chromium supplementation in the present and others studies.

The associated supplementation of $0.8 \mathrm{mg}$ $\mathrm{kg}^{-1}$ of chromium-yeast and $0.6 \mathrm{mg} \mathrm{kg}^{-1}$ of seleniumyeast in the diet does not modify the performance and quantitative characteristics of the carcass of barrows in the finishing phase.

\section{ACKNOWLEDGEMENTS}

The authors thank the Fundação de Apoio ao Desenvolvimento do Ensino, Ciência e Tecnologia do Estado de Mato Grosso do Sul (FUNDECT), Conselho Nacional de Desenvolvimento Científico e Tecnológico (CNPq), Universidade Federal de Mato Grosso do Sul (UFMS), and Coordenação de Aperfeiçoamento de Pessoal de Nível Superior - Brasil (CAPES; Finance Code 001) for the financial support in the execution of the research project.

\section{BIOETHICS AND BIOSSECURITY COMMITTEE APPROVAL}

The project was approved by the ethics committee in the use of animals, protocol number 625/2014 - Universidade Federal de Mato Grosso do Sul (UFMS).

\section{DECLARATION OF CONFLICT OF INTERESTS}

The authors declare no conflict of interest. The 
funding sponsors had no role in the design of the study; in the collection, analyses, or interpretation of data; in the writing of the manuscript, and in the decision to publish the results.

\section{AUTHORS' CONTRIBUTIONS}

All authors contributed equally for the conception and writing of the manuscript. All authors critically revised the manuscript and approved of the final version.

\section{REFERENCES}

AMATA, I. A. Chromium in livestock nutrition: A review. Global Advanced Research Journal of Agricultural Science, p.289-306, 2013. Available from: <https:// s3.amazonaws.com/academia.edu.documents/32875607/ GARJAS 2013.pdf?AWSAccessKeyId=AKIAIWOWYYG Z2Y53UL3A\&Expires $=1532715435 \&$ Signature $=H m A E \% 2$ FyPhSOONpF\%2BSk1g03mXLecs\%3D\&response-contentdisposition=inline $\% 3 \mathrm{~B} \% 20$ filename $\% 3$ DGARJAS_2013. pdf>. Accessed: Jun. 4, 2018.

ARTHUR, J. R. et al. Selenium in the immune system. The Journal of Nutrition, v.133 p.1457S-1459S, 2003. Available from: $<$ https://www.ncbi.nlm.nih.gov/pubmed/12730442>. Accessed: Jun. 9, 2018.

BRIDI, A. M.; SILVA, C. A. Métodos de avaliação de carcaça e da carne suína. Londrina (PR): Midiograf. 2007.

BRIDI, A. M.; SILVA, C. A. Avaliação da carne suína. Londrina (PR): Midiograf. 2009.

CARAMORI JÚNIOR, J. G. et al. Chromium and seleniumenriched yeast for castrated finishing pigs: effects on performance and carcass characteristics. Semina: Ciências Agrárias, v.38, 2017. Available from: <http://www.uel.br/revistas/uel/index. php/semagrarias/article/view/29598>. Accessed: Aug. 25, 2019. doi: $10.5433 / 1679-0359.2017 \mathrm{v} 38 \mathrm{n} 6 \mathrm{p} 3851$

JANG, Y. D. et al. Comparison of bioavailability of organic selenium sources in finishing pigs. Asian-Australasian Journal of Animal Sciences, v.23, p.931-936, 2010. Available from: $<\mathrm{https}$ // doi.org/10.5713/ajas.2010.90619>. Accessed: Jun. 9, 2018. doi: 10.5713/ajas.2010.90619.

KUMAR, N. et al. Selenium supplementation influences growth performance, antioxidant status and immune response in lambs. Animal Feed Science and Technology, v.153, p.77-87, 2009. Available from: <https://oi.org/10.5713/ ajas.2010.90619>. Accessed: Aug. 25, 2019. doi: 10.1016/j. anifeedsci.2009.06.007.

LI, Y. S. et al. Effects of dietary chromium methionine on growth performance, carcass composition, meat colour and expression of the colour-related gene myoglobin of growing-finishing pigs. AsianAustralasian Journal of Animal Sciences, v.26, p.1021-1029, 2013. Available from: <https://doi.org/10.5713/ajas.2013.13012>. Accessed: Jun. 22, 2018. doi: 10.5713/ajas.2013.13012.

LIEN, T. F. et al. Effects of supplemental levels of chromium picolinate on the growth performance, serum traits, carcass characteristics and lipid metabolism of growing-finishing pigs. Animal Science, v.72, p.289-296, 2001. Available from: <https://doi.org/10.1017/ S1357729800055788>. Accessed: Jun. 7, 2018. doi: 10.1017/

\section{S1357729800055788}

MARCOLLA, C. S. et al. Chromium, CLA, and ractopamine for finishing pigs. Journal of Animal Science, v.95, p.44724480, 2017. Available from: <https://doi.org/10.2527/ jas2017.1753 >. Accessed: Aug. 25, 2019. doi: 10.2527/ jas2017.1753.

MARTÍNEZ-GÓMEZ, N. et al. Effect of selenium-enriched yeast and sodium selenite on finishing pigs diets on intramuscular fat and fatty acids. Tropical and Subtropical Agroecosystems, v.15, p.41-46, 2012. Available from: <http://www.redalyc.org/ pdf/939/93924483004.pdf>. Accessed: Jul. 12, 2018.

MATEO, R. D. et al. Efficacy of dietary selenium sources on growth and carcass characteristics of growing-finishing pigs fed diets containing high endogenous selenium. Journal of Animal Science, v.85, p.1177-1183, 2007. Available from: <https://doi. org/10.2527/jas.2006-067>. Accessed: Jul. 15, 2018. doi: 10.2527/ jas.2006-067.

MATTHEWS, J. O. et al. Effect of chromium picolinate and chromium propionate on glucose and insulin kinetics of growing barrows and on growth and carcass traits of growingfinishing barrows. Journal of Animal Science, v.79, p.21722178, 2001. Available from: <https://www.ncbi.nlm.nih.gov/ pubmed/11518226>. Accessed: Jul, 2, 2018.

MATTHEWS, J. O. et al. Effects of chromium propionate on growth, carcass traits, and pork quality of growing-finishing pigs. Journal of Animal Science, v.83, p.858-862, 2005. Available from: $<$ https://www.ajas.info/upload/pdf/18 63.pdf $>$. Accessed: Jul. 11, 2018.

NIENABER, J. A. et al. Thermal environment effects on growing-finishing swine Part I-Growth, feed intake and heat production. Transactions of the ASAE, v.30, p.17721775, 1987. Available from: <https://elibrary.asabe.org/ abstract.asp?aid=30635>. Accessed: Mar. 11, 2020. doi: $10.13031 / 2013.30635$.

PERES, L. M. et al. Effect of supplementing finishing pigs with different sources of chromium on performance and meat quality. Revista Brasileira de Zootecnia, v.43, p.369375, 2014. Available from: <https://doi.org/10.1590/S151635982014000700005>. Accessed: Jul. 20, 2018. doi: 10.1590/ S1516-35982014000700005.

ROSTAGNO, H. S. et al. Tabelas brasileiras para aves e suínos: composição de alimentos e exigências nutricionais. $3^{\text {a }}$ Edição. Editora UFV, Viçosa, MG, 2011

ROSTAGNO, H. S. et al. Tabelas brasileiras para aves e suínos: composição de alimentos e exigências nutricionais. $4^{\text {a }}$ Edição. Editora UFV, Viçosa, MG, 2017

SAKOMURA, N. K. et al. Nutrição de não ruminantes. Jaboticabal: FUNEP, 678p, 2014

SALES, J; JANCÍK, F, Effects of dietary chromium supplementation on performance, carcass characteristics, and meat quality of growing-finishing swine: A meta-analysis. Journal of Animal Science, v.89, p.4054-4067, 2011. Available from: $<$ https://doi.org/10.2527/jas.2010-3495>. Accessed: Jun. 15, 2018. doi: $10.2527 /$ jas.2010-3495

STEFANKA, P. et al. The analysis of the carcass characteristics

Ciência Rural, v.50, n.11, 2020. 
and physical-technological quality of pork after the using diet with the addition of organic chromium and selenium. Journal of Central European Agriculture, v.14, p.189-196, 2013. Available from: <https://doi.org/10.5513/JCEA01/14.3.1302>. Accessed: Jul. 20, 2018. doi: 10.5513/JCEA01/14.3.1302.

STUPKA, R. et al. The effect of organic selenium and the duration of its use on selected indicators of fattening capacity and carcass value in hybrid pigs. Research in Pig Breeding, 6, 2012. Available from: <http://www.respigbreed.cz/2012/1/11 pdf>. Accessed: Jun. 20, 2018.

TIAN, Y. Y. et al. Effects of chromium methionine supplementation on growth performance, serum metabolites, endocrine parameters, antioxidant status, and immune traits in growing pigs. Biological Trace Element Research, v.162, p.134-141, 2014. Available from: <https://doi.org/10.1007/ s12011-014-0147-9>. Accessed: Jun. 15, 2018. doi: 10.1007 s12011-014-0147-9.

TIAN, Y. Y. et al. Effects of graded levels of chromium methionine on performance, carcass traits, meat quality, fatty acid profiles of fat, tissue chromium concentrations, and antioxidant status in growingfinishing pigs. Biological Trace Element Research, v.168, p.110121, 2015. Available from: <https://doi.org/10.1007/s12011-0150352-1>. Accessed: Jun. 11, 2018. doi: 10.1007/s12011-015-0352-1.

WOLTER, B. et al. Influence of dietary selenium source on growth performance, and carcass and meat quality characteristics in pigs. Canadian Journal of Animal Science, v.79, p.119121, 1999. Available from: <https://doi.org/10.4141/A98-028>. Accessed: Jun. 27, 2018. doi: 10.4141/A98-028.

ZHANG, H. et al. Effect of chromium picolinate supplementation on growth performance and meat characteristics of swine. Biological Trace Element Research, v.141, p.159-169, 2011. Available from: <https://doi.org/10.1007/s12011-010-8727-9>. 